UDC 51-76

DOI: $10.21668 /$ health.risk/2021.1.02.eng

Research article

\title{
NUMERIC MODELING OF BACTERIA POPULATION EVOLUTION IN HUMAN LUNGS
}

\author{
N.E. Pil ${ }^{1}$, V.M. Chigvintsev ${ }^{2}$ \\ ${ }^{1}$ Perm National Research Polytechnic University, 29 Komsomolskiy Ave., Perm, 614990, Russian Federation \\ ${ }^{2}$ Federal Scientific Center for Medical and Preventive Health Risk Management Technologies, 82 Monastyrskaya Str., \\ Perm, 614045, Russian Federation
}

\begin{abstract}
The present work focuses on building up a mathematical model showing bacteria population evolution in human lungs taking into account dynamics of immune processes; the model would be useful for assessing functional damage to the lungs. Numeric modeling of processes that occur in a human body is a promising tool for analyzing and predicting impacts exerted by risk factors on health. The suggested approach was developed within a concept describing a human body as a multi-level model that allowed for interaction between various systems and functional state of examined organs given effects produced on them by different adverse factors. Since direct modeling of the structure and processes occurring in the lungs is rather complicated, these organs are usually described with a porous medium model and it requires a lot of computing resources. Damage to the lungs determined via an evolution equation was introduced into the model. The equation described dependence between damage and infiltrate distribution and effects produced on alveolar cells by toxicants excreted by bacteria.

The work dwells on certain results that characterize how concentrations of immune system components and bacteria population are spatially distributed when an immune response is evolving. Our research provides a qualitative insight into reasons for quantitative changes in bacteria population under immune reactions occurring in a body under exposure to different factors. This approach can be used for obtaining more precise parameters for existing population models that show spread and clinical course of bacterial infections and for making a long-term prediction of an epidemiological situation. Results obtained with this approach can be useful for analyzing risks of communicable diseases including those occurring under exposure to adverse environmental factors.

Key words: mathematical modeling, immune response, bacteria population, toxin extraction, functional damage, human lungs, porous medium, multi-component mixture flow.
\end{abstract}

People constantly interact with the environment throughout their lives as they get all the necessary substances from it and are exposed to its adverse effects. Influence exerted on people by adverse environmental factors results in their deteriorating health; contagion with bacterial flora is a possible cause for health disorders.

At present there are different clinical laboratory and functional techniques aimed at observing and examining processes that occur in a human body. Such techniques allow obtaining a complex insight into a current situation with a patient's health. However results obtained via such techniques give a picture of a patient's health only for a moment at which measurements are made and they do not provide any opportunity to make forecasts $[1,2]$. These techniques are based on analyzing various tests with their results being compared with physiological standard ranges; basing on it, experts make conclusions on a patient's health. Besides, a lot of such techniques are rather expensive and labor-consuming.

Mathematical modeling seems to be a completely different approach used for more profound examining and predicting processes that occur in various organs in a body. A lot of field observations that are rather painstaking can be replaced with computing experi-

(C) Pil N.E., Chigvintsev V.M., 2021

Nikita E. Pil - Student (e-mail: nikitapil32@gmail.com; tel.: +7 (919) 467-49-69; ORCID: https://orcid.org/0000-0003-2312-3006).

Vladimir M. Chigvintsev - Candidate of Physical and Mathematical Sciences, Researcher at Mathematic Modeling of Systems and Processes Department (e-mail: cvm@fcrisk.ru; tel.: +7 (342) 237-18-04; ORCID: https://orcid.org/0000-0002-0345-3895). 
ments that involve using mathematical models. Mathematic modeling procedures allow saving time and resources, changing initial conditions, and analyzing a disease development as per different scenarios. It means that the approach is truly universal as we can use the same mathematical model for different cases of the same disease.

Creation of a model that shows how bacterial population evolves in the human lungs is a part of the more general task which is to create a mathematical model for describing a human body as an interconnected set of organs and systems; certain functional damage is to be introduced into it for each organ in order to show an extent to which functions of this organ are distorted [3]. Damage changes within a range from 0 to 1 ( 0 means that there are no functional disorders and 1 mans that an organ doesn't perform its functions at all). This model includes sub-models showing the digestive, immune, endocrine, and respiratory systems [4-6].

Dynamics of pathogenic microorganisms' growth and their spatial distribution can be described with population models. Bearing basic principles description in mind, interesting models seem to be the Monod model [7] stating that number of population depends on a nutrient medium, and the Lotka - Volterra model [8] that describes competition between populations. Cellular automations are used in several works [9-12] to describe how a population is distributed in space. A modeled area is discretized, values of population number are assigned to certain meshes, and rules for a population movement are fixed. These models have a drawback which is a too complicated transfer from two-dimensional tasks to three-dimensional ones as well as difficulties in biophysical interpretation of rules for cellular automations functioning. There are interesting models among those with continuous time [13, 14]; these works focus on evolution processes occurring in bacterial populations used in oil extraction industry. A bacterial population moves due to pressure gradient and diffusion occurrence. The model is described with a system of differential equations in partial derivatives.
Basic principles for building up immunological models are described in the work [15] that concentrates on population of pathogenic microorganisms taken in dynamics and immune system components. Interconnections between elements in the model are built as per «predator - prey» type and are described with a system of non-linear differential equations with retarded argument. Retardation is introduced to describe spatial effects that are not obviously taken into account in the model. The works [16-18] give more detailed description of immune response mechanisms but they fail to take into account spatial distribution of pathogenic population and immune system cells.

Describing immune processes occurring in human lungs in dynamics requires taking into account medium behavior. There are various models that describe human lungs and respiratory processes. The work [19] dwells on actual respiratory tracts geometry; however, this approach to describing processes requires substantial computing resources. It seems promising to use porous medium model and filtration theory to create models showing the lower respiratory tracts $[6,20,21]$.

Therefore, many immunologic models do not obviously describe spatial distribution of examined features in a specific human organ. It seems possible to use approaches and procedures related to mechanics of multi-component mixture flows in porous media taking influence exerted by immunologic processes into account.

Our research goal was to build a mathematical model showing bacterial population evolution in the human lungs taking into account dynamics of immune processes in order to assess functional damage to the lungs.

Data and methods. Communicable diseases involve pathogenic microorganisms penetrating and/or activating in a human body. This work dwells on bacterial population evolution localized in the lower respiratory tracts. Basic features used to describe the population include division rate, parameters determining nutrient medium (substrate) quantity, bacteria being able to move in a medium on their own and to produce toxicants. 
It is well known that it is more energetically beneficial for a body to maintain pathologic antigen concentration on a certain level than remove it completely [15]. A bacterial population starts to grow in case the immune system is weakened due to a previous disease or pathogenic microorganisms penetrating a body from the environment. Simultaneously an immune response mechanism is being activated. As a result there are inflammations where a bacterial population concentrates. Discharge related to immune system reactions leads to a decrease in lung capacity thus resulting in lower oxygen introduction and more frequent breathing. Bacteria produce toxins that have adverse effects on alveoli cells as they deteriorate their barrier and transportation functions.

All the described processes take place in the lower respiratory tracts in the human lungs. The lungs are a set of airways with alveoli as their ends (Figure 1) [22].

Adult lungs contain approximately 600 700 million alveoli and it creates certain difficulties in direct modeling of the overall respiratory tracts hierarchy. And mathematical description of processes that occur in the lungs requires substantial computing resources. These computing difficulties might be overcome via using a porous medium model. The lungs are considered a continuous saturated elastically deformed porous medium. Deformation occurs due to diaphragm contraction or ribs lifting and as a result lung volume decreases, pressure increases, and a person exhales. When a person inhales, lung volume increases and pressure in them drops lower than the atmospheric one, and due to it air enters a human body. This approach is described in great detail in [6].

Porous medium model allows replacing detailed structure of alveoli and alveolar channels (Figure 2) with porosity and permeability. Porosity is a dimensionless value that characterizes a share belonging to pores in a medium and is equal to a ratio between volume of pores and overall volume of a medium that consists of pores and elastic cross connections. Permeability is capacity of a medium to let through liquids and gases.

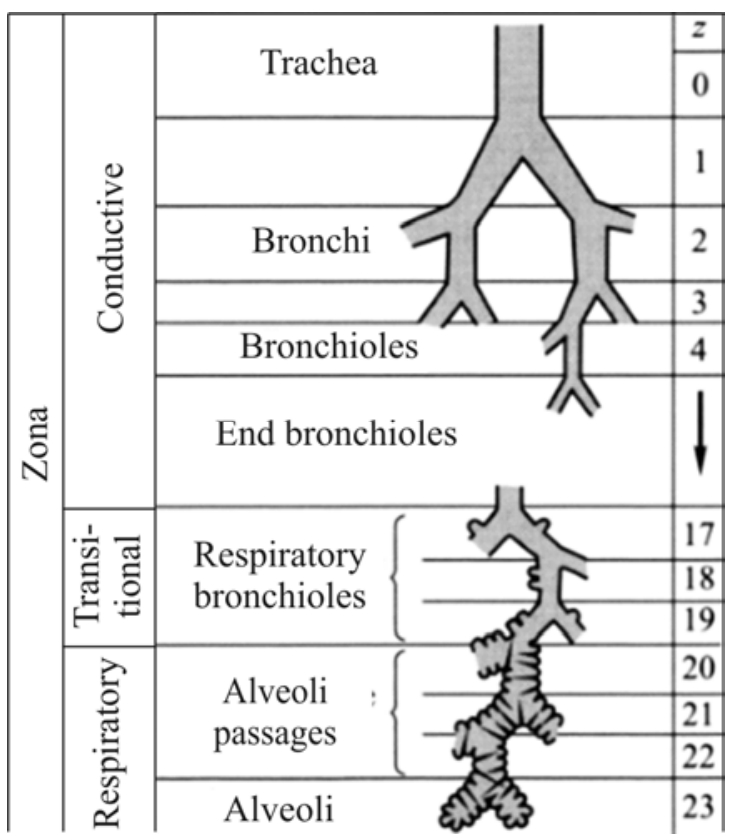

Figure 1. Lower airways dichotomy as per Veibel morphometric model [22]

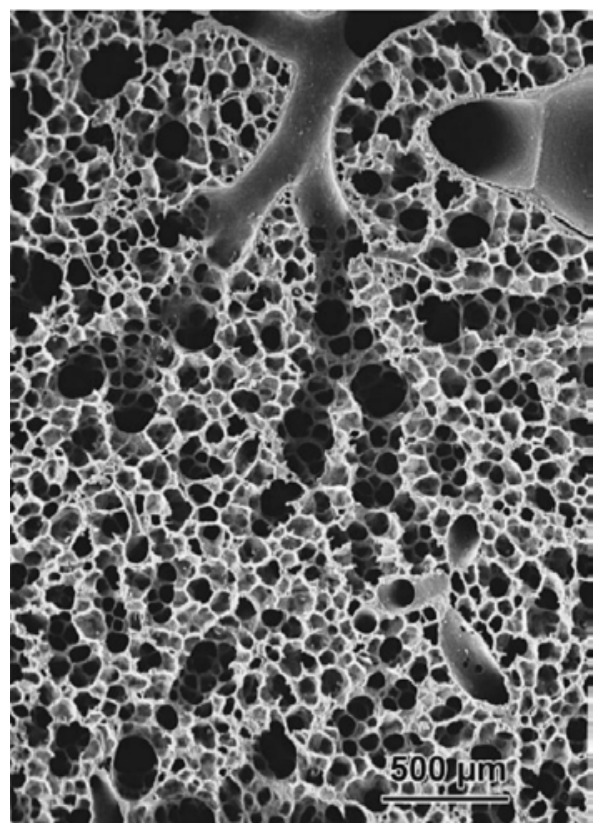

Figure 2. An increased fragment of alveoli [23]

Damage to the lungs changes due to infiltrate occurring during an immune response and influence exerted on alveoli cells by toxicants produced by bacteria. Within porous medium model framework porosity and permeability will go down during an immune response due to alveoli space being obstructed.

Let us consider mathematical task setting; to do that, let us take the following mass balance equation: 


$$
\frac{\partial \rho}{\partial t}+\nabla \cdot(\rho v)=-\nabla \cdot j+S,
$$

where $\rho$ is mixture density, $v$ is velocity vector, $\nabla$ is Hamilton operator, $j$ is diffusion flow vector. Moving on to concentrations and assuming that the mixture is non-compressible, we get the following:

$$
\begin{gathered}
\frac{d C_{i}}{d t}=-\nabla \cdot j_{i}, \\
j=-D \nabla C,
\end{gathered}
$$

where $\frac{d}{d t}=\frac{\partial}{\partial t}+v \cdot \nabla$ is total derivative, $D$ is diffusion coefficient.

Therefore, taking porosity $m$ into account, we get mass transfer equation in porous medium:

$$
\frac{\partial(m C)}{\partial t}+m v \cdot \nabla C=\nabla \cdot(m D \nabla C)+S,
$$

In our first approximation let us consider that the examined components move due to diffusion occurring due to concentration gradients. In this case overall transfer equation is as follows:

$$
\frac{\partial\left(m C_{i}\right)}{\partial t}=\nabla \cdot\left(m D_{i} \nabla C_{i}\right)+S_{i},
$$

where $C_{i}$ is concentration of bacterial population $(i=1)$, substrate $(i=2)$, macrophages $(i=3)$, plasma cells $(i=4)$, antibodies $(i=5)$, and toxins $(i=6)$ accordingly; $S_{i}$ is a mass source of the $i$-th component in the mixture.

Bacterial population grows due to division and substrate consumption and decreases due to natural lysis and effects produced by macrophages and antibodies:

$$
S_{1}=\mu \frac{C_{2}}{k_{1}+C_{2}} C_{1}-k_{2} C_{1}^{2}-\gamma_{13} C_{3} C_{1}-\gamma_{15} C_{5} C_{1} .
$$

Substrate concentration goes down due to it being consumed by a bacterial population and recovers due to regeneration processes:

$$
S_{2}=-k_{3} \mu \frac{C_{2}}{k_{1}+C_{2}} C_{1}+\gamma_{2} f\left(1-\frac{C_{2}}{C_{2,0}}\right) \text {. }
$$

Changes in concentrations of immune system components (macrophages, plasmatic cells, and antibodies) are given as:

$$
\begin{aligned}
& S_{3}=\gamma_{31} \xi C_{3}-\alpha_{3} C_{3}, \\
& S_{4}=\gamma_{4} \xi\left[\rho_{4} C_{3} C_{4}-C_{3} C_{4}\right]-\alpha_{4}\left(C_{4}-C_{4,0}\right), \\
& S_{5}=\rho_{5} \xi C_{4}-\eta_{5} \gamma_{51} C_{5} C_{1}-\alpha_{5} C_{5} .
\end{aligned}
$$

Toxicants concentration is proportionate to bacterial population concentration and goes down due to natural neutralization:

$$
S_{6}=\gamma_{6} C_{1}-\alpha_{6} C_{6} .
$$

The

equations

Ошибка! Источник ссылки не найден.Ошибка! Источник ссылки не найден. with initial and border conditions create a system of equations in partial derivatives that describes bacterial population evolution in a porous medium.

The functions $\xi=\xi(h)$ describe effects produced by damage $h$ on the immune system functioning. Damage grows due to effects produced by toxicants and alveoli obstruction and can decrease due to self-recovery:

$$
\frac{d h}{d t}=a_{1} C_{6}+a_{2} C_{1}-\alpha_{h} h .
$$

Taking into account (9) the system (4)-(8) shows complete mathematical task setting that includes correlations for describing changes in concentration due to diffusion processes and correlations for mass sources occurring as a result of an immune response.

Results and discussion. To test quality of the obtained model, numeric experiments were used; they allowed obtaining spatiotemporal distribution of bacterial population concentrations and concentrations of the immune system components.

At the initial time bacterial population distribution and concentrations were assumed to be known. Bacterial population localization was taken into account, and initial distribution is shown in Figure 3. We considered how bacterial population concentration spread in po- 
rous medium volume. The considered scenario described bacterial population death.

Concentrations of the immune system components were distributed evenly inside the

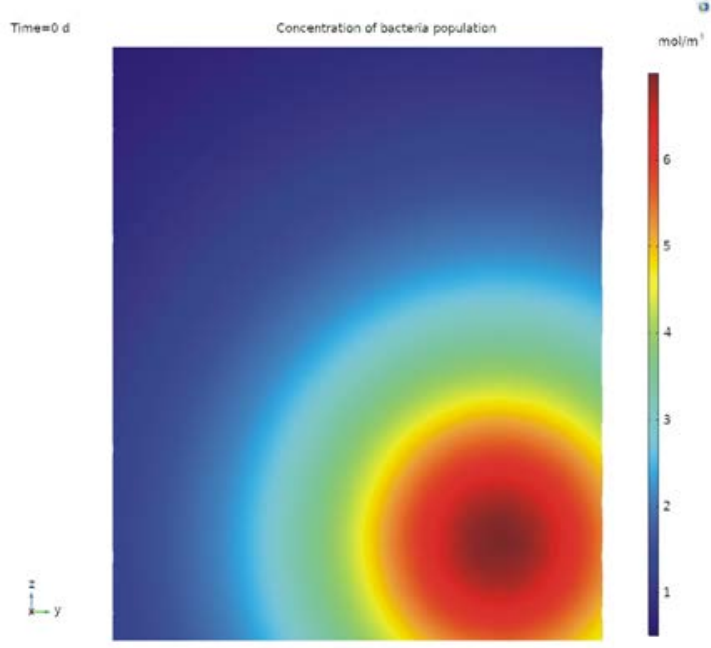

Figure 3. Initial distribution of bacterial population concentration

modeled area. Distribution of toxins concentration coincided with bacterial population distribution at the initial time.

Figure 4 shows spatial distribution of bacterial population concentration during an immune response. Over time a bacterial population grows in volume as its number increases. Then an immune response mechanism is activated and at a certain time (time $=9$ day) we can see a decrease in a bacterial population due to effects produced by macrophages and antibodies.

Figure 5 shows integral curves that describe immune cells population and bacterial population. It is obvious that a bacterial population first grows intensely and it leads to generation and growth in number of immune cells population; pathogenic microorganisms are neutralized and bacterial population decreases.

We also considered another scenario that involved bacterial population survival; it might result in an organ death considering its total inability to perform its basic functions. In this scenario a bacterial population starts to grow uncontrollably and it indicates that an immune response is unable to neutralize pathogenic flora. Integral curves showing number of immune system components and bacteria population are given in Figure 6.

Two considered scenarios had different parameters that characterized the immune system state and parameters that described a bacterial population. These results give a qualitative picture of immune processes occurring due to a bacterial disease in the human lungs. We should note that models that are being developed at the moment are individual in many aspects and depend on peculiarities of a specific body such as age, current state of the immune system, genetics, and diseases in a case history.

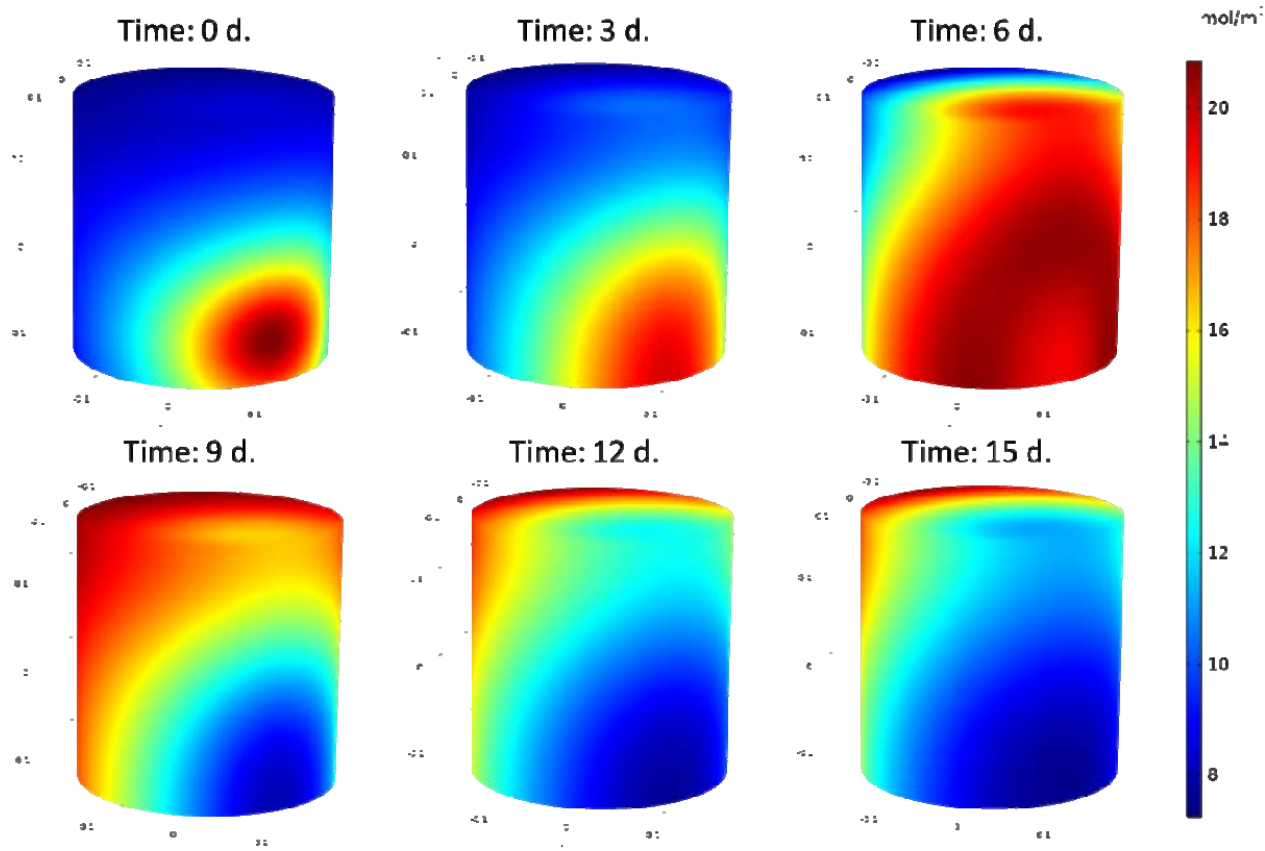


Figure 4. Distribution of the concentration of the bacterial population in a porous medium

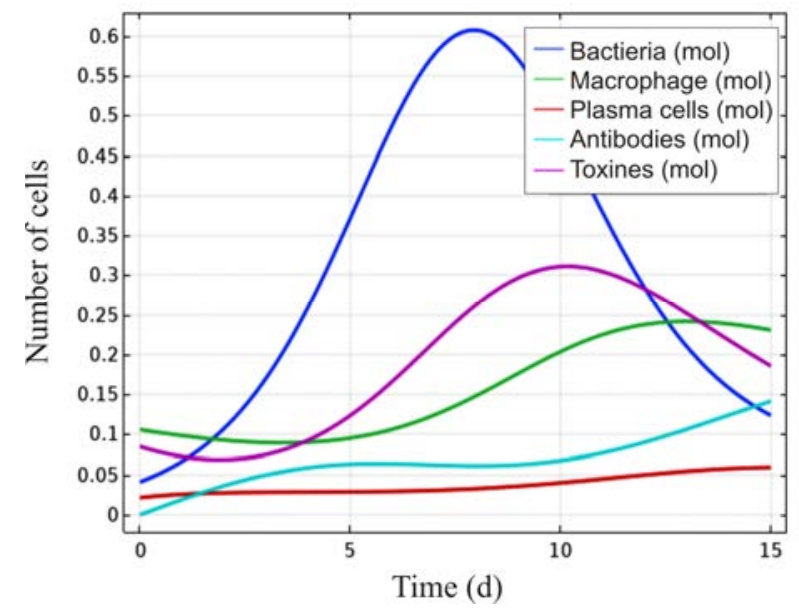

Figure 5. Integral assessment of immune components concentration and bacterial population concentration in the examined volume of porous medium (bacterial population death)

The obtained results are well in line with those given in the works $[14,18]$.

Conclusion. The work dwells on the model showing bacterial population evolution in the human lungs and contains conceptual and mathematical setting. It also focuses on results obtained via numeric experiments that describe scenarios involving either bacterial population death or survival. Immune processes development is determined by a state of a body and bacterial population peculiarities.

In future we plan to take into account influence exerted by breathing on bacterial population cells moving and to enhance a set of immune response elements. We plan to accomplish numeric examinations of effects produced by damage on the immune system functioning in the human lungs.

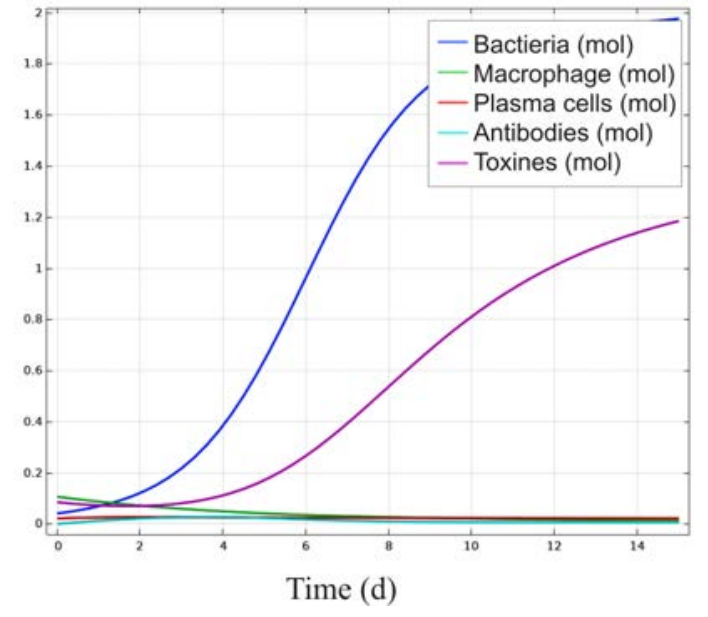

Figure 6. Integral assessment of immune components concentration and bacterial population concentration in the examined volume of porous medium (bacterial population survival)

The described results can be seen as making a certain contribution into developing procedures for mathematical modeling aimed at describing immune response and physics of multicomponent mixture flow in porous media. To make practical use more efficient, it is advisable to enhance a list of immune system components and their interconnections. A promising trend in the model development might be efforts aimed at identifying model parameters and examining the model in order to detect new regularities in immune processes.

Acknowledgements. The authors express their gratitude to Professor Petr V. Trusov for scientific advice and valuable comments on the text.

Funding. The research was not granted any sponsor support.

Conflict of interests. The authors declare there is no any conflict of interests.

\section{References}

1. Grebenev A.L. Propedevtika vnutrennikh boleznei [Preliminary study of internal diseases]. Moscow, Meditsina Publ., 2001, 592 p. (in Russian).

2. Shklyar B.S. Diagnostika vnutrennikh boleznei [Internal diseases diagnostics]. Kiev, Vysshaya shkola Publ., 1972, 516 p. (in Russian).

3. Trusov P.V., Zaitseva N.V., Kir'yanov D.A., Kamaltdinov M.R., Tsinker M.Yu., Chigvintsev V.M., Lanin D.V. A mathematical model for evolution of human functional disorders influenced by environment factors. Matematicheskaya biologiya i bioinformatika, 2012, vol. 7, no. 2, pp. 589-610 (in Russian). 
4. Zaitseva N.V., Shur P.Z., Aminova A.I., Kir'yanov D.A. To estimate the additional risk of diseases of the gastrointestinal tract associated with dysbiosis of the intestinal microflora due to the impact of tetracycline residues in foods. Zdorov'e naseleniya i sreda obitaniya, 2012, vol. 232, no. 7, pp. 46-48 (in Russian).

5. Trusov P.V., Zaitseva N.V., Chigvintsev V.M., Lanin D.V. Regulation of organism's antiviral immune response: mathematical model, qualitative analysis, results. Matematicheskaya biologiya $i$ bioinformatika, 2018, vol. 13, no. 2, pp. 402-425 (in Russian).

6. Trusov P.V., Zaitseva N.V., Tsinker M.Yu. On modeling of airflow in human lungs: constitutive relations to describe deformation of porous medium. Vestnik Permskogo natsional'nogo issledovatel'skogo politekhnicheskogo universiteta. Mekhanika, 2020, no. 4, pp. 165-174 (in Russian).

7. Monod J. The growth of bacterial cultures. Annual Review of Microbiology, 1949, vol. 3, pp. 371-394. DOI: 10.1146/annurev.mi.03.100149.002103

8. Framstad E., Stenseth N.C., Bjornstad O.N., Falck W. Limit cycles of Norwegian lemmings: tensions between phase-dependence and density-dependence. Phil. Trans. R. Soc. Lond. B, 1997, vol. 264, no. 1378 , pp. 31-38. DOI: 10.1098/rspb.1997.0005

9. Butov A.A., Egorov A.G. The model of one-type population dynamics in space and time. Vestnik Kemerovskogo gosudarstvennogo universiteta, 2015, vol. 64, no. 4-3, pp. 121-127 (in Russian).

10. Hong M., Xiaojuan Z. Microbial growth modeling and simulation based on cellular automata. Research Journal of Applied Sciences, Engineering and Technology, 2013, vol. 6, no. 11, pp. 2061-2066. DOI: 10.19026/RJASET.6.3824

11. Klimenko A.E., Matushkin Y.G., Kolchanov N.A., Lashin S.A. Modeling evolution of spatially distributed bacterial communities: a simulation with the haploid evolutionary constructor. BMC Evolutionary Biology, 2015, vol. 15, no. 1, pp. 1-11. DOI: 10.1186/1471-2148-15-S1-S3

12. Harrouet F., Desmeulles G., Redou P., Guabert L. 3D individual based for bacteria growth and spatial interactions: application to the case of Listeria Monocytogenes and Carnobacterium Piscola. Jan Van Impe. Food Sim, 2016, 6 p.

13. Ginak A.I., Kuznetsova S.N., Milovanovich E.V. Simulation of biochemical processes in oil extraction well face zone. Izvestiya Sankt-Peterburgskogo gosudarstvennogo tekhnologicheskogo instituta, 2012, vol. 41, no. 15, pp. 82-83 (in Russian).

14. Kholodonov V.A., Lukina M.V., Milovanovich E.V. Modelirovanie biotekhnologicheskikh i fil'tratsionnykh protsessov povysheniya nefteotdachi plastov [Modeling biotechnological and filtration processes related to a growth in recoverable oil]. Izvestiya Sankt-Peterburgskogo gosudarstvennogo tekhnologicheskogo instituta, 2011, vol. 37, no. 11, pp. 69-71 (in Russian).

15. Marchuk G.I. Matematicheskie modeli v immunologii. Vychislitel'nye metody i eksperimenty [Mathematical models in immunology. Computational approaches and experiments]. Moscow, Nauka Publ., 1991, 304 p. (in Russian).

16. Levchenko O.Yu. Mathematical modeling of antibacterial immune reaction. Politematicheskii setevoi elektronnyi nauchnyi zhurnal kubanskogo gosudarstvennogo agrarnogo universiteta, 2011, no. 66, pp. 60-71 (in Russian).

17. Smith A.M., McCullers J.A., Adler F.R. Mathematical model of a three-stage innate immune response to a pneumococcal lung infection. Journal of Theoretical Biology, 2011, vol. 7, no. 276 (1), pp. 106-116. DOI: 10.1016/j.jtbi.2011.01.052

18. Kuznetsov S.R. Mathematical model of the immune response. Vestnik Sankt-Peterburgskogo universiteta. Prikladnaya matematika. Informatika. Protsessy upravleniya, 2015, no. 4, pp. 72-87 (in Russian).

19. Lambert A.R. Regional deposition of particles in an image based airway model: CFD simulation and left-right lung ventilation asymmetry. Iowa, University of Iowa Publ., 2010, 68 p.

20. De Groot C.T., Straatman A.G. A conjugate fluid-porous approach for simulating airflow in realistic geometric representations of the human respiratory system. Journal of Biomechanical Engineering, 2016, vol. 138, no. 3, pp. 4032113. DOI: 10.1115/1.4032113 
21. DeGroot C.T., Straatman A.G. Towards a porous media model of the human lung. 4th International Conference on Porous Media and its Applications in Science: AIP Conference Proceedings, 2012, vol. 1453, no. 1, pp. 69-74. DOI: 10.1063/1.4711155

22. Veibel' E.R. Morfometriya legkikh cheloveka [Human lungs morphometry]. Moscow, Meditsina Publ., 1970, 175 p. (in Russian).

23. Weibel E.R. What makes a good lung? Swiss Med. Wkly, 2009, vol. 139, no. 27-28, pp. 375-386.

Pil N.E., Chigvintsev V.M. Numeric modeling of bacteria population evolution in human lungs. Health Risk Analysis, 2021, no. 1, pp. 15-22. DOI: 10.21668/health.risk/2021.1.02.eng

Received: 01.03.2021

Accepted: 19.03.2021

Published: 30.03 .2021 